\title{
Protein Losing Enteropathy after Fontan Surgery - Clinical and Diagnostical Aspects
}

\author{
Attila Tárnok József Bocsi Dominik Lenz Jan Janousek \\ Department of Pediatric Cardiology, Cardiac Center Leipzig GmbH, University of Leipzig, Germany
}

\section{Key Words}

Protein losing enteropathy - Univentricular heart . TCPC - Hypoproteinemia - Elevated fecal alpha1 antitrypsin · Immunosuppression - T Iymphocytes

\section{Summary \\ Protein losing enteropathy (PLE) is the massive enteric loss of serum protein. PLE may appear in several dis- eases associated with intestinal mucous membrane damages with or without infection. PLE is mostly associ- ated with total cavopulmonary connection (TCPC) or Fontan-type circulation in patients with a functionally univentricular heart. TCPC is performed at an age of about 2 years or older and has a high survival rate of $>90 \%$. Time of PLE onset after TCPC is variable, the exact etiology is still unclear. Increased central venous pres- sure due to the absence of a subpulmonary ventricle may be a main reason for PLE, affecting $2-15 \%$ of the pa- tients with a survival rate of $40 \%$ at 5 years and $20 \%$ at 10 years. Also immunological reasons for PLE are suspect- ed. Major clinical signs are edemas, ascites, pleural effu- sion, diarrhea, malnutrition, fatigue, weight loss, and re- duced physical development. The most impaired labora- tory signs are elevated fecal $\alpha 1$-antitrypsin and $\alpha 1$-anti- trypsin clearance, hypoproteinemia (hypoalbuminemia, hypo- $\gamma$-globulinemia), Iymphopenia (selective $\mathrm{T}$ helper cell loss) and secondary lymphangiectasia. Therapy con- siderations should have the aim to decrease central ve- nous pressure to improve hemodynamics. Medical treat- ment consists of substitution of e.g. albumin, $\gamma$-globulin, glucocorticoid, heparin or calcium, but still $>60 \%$ of the patients remain symptomatic.}

\section{Schlüsselwörter}

Eiweißverlustsyndrom · Univentrikuläres Herz · TCPC . Hypoproteinämie · Erhöhtes fäkales Alpha-1-Antitrypsin - Immunsuppression · T-Lymphozyten

\section{Zusammenfassung}

Die Proteinverlustenteropathie (PLE oder Eiweißverlustsyndrom) ist durch einen massiven enteralen Verlust von Serumeiweiß gekennzeichnet. PLE kann bei verschiedenen Erkrankungen, die mit der Beschädigung der Darmmukosa einhergehen, mit und ohne eine begleitende Infektion auftreten. PLE ist zumeist mit einer totalen cavopulmonalen Verbindung (total cavopulmonary connection; TCPC) oder einer Fontan-Kreislaufoperation bei Patienten mit einem funktionell univentrikulären Herzen assoziiert. Die TCPC wird in einem Alter von 2 Jahren oder älter durchgeführt und hat eine hohe Überlebensrate von $>90 \%$. Der Beginn des PLE nach TCPC ist sehr variabel, die genaue Ätiologie ist unbekannt. Der zentralvenöse Druck bleibt erhöht aufgrund des Fehlens des subpulmonalen Ventrikels. Dies ist möglicherweise eine der Hauptursachen für PLE und betrifft 2-15\% der Patienten. Die Überlebensrate ist nach 5 Jahren $40 \%$ und nach 10 Jahren $20 \%$. Es gibt auch Hinweise für immunologische Ursachen des PLE. Die klinischen Hauptbefunde sind Ödeme, Aszites, Pleuraerguss, Diarrhö, Mangelernährung, Müdigkeit, Gewichtsverlust und Entwicklungsstörungen. Die am stärksten betroffenen Laborbefunde sind erhöhtes $\alpha 1$-Antitrypsin im Stuhl und erhöhte $\alpha 1$-Antitrypsin-Clearance, Hypoproteinämie (Hypoalbuminämie, Hypo- $\gamma$-Globulinämie), Lymphopenie (selektiver T-HelferZell-Verlust), sekundäre Lymphangiektasie. Die therapeutische Überlegungen sollten mit der Verbesserung der Hämodynamik beginnen und die Verringerung des zentralvenösen Drucks zum Ziel haben. Die Medikation erfolgt symptomatisch, z.B. Albumin-, $\gamma$-Globulin-, Glukokortikoid-, Heparin- oder Kalziumsubstitution. Trotz Behandlung bleiben über $60 \%$ der Patienten symptomatisch.

\begin{tabular}{ll}
\hline KARGER & @ 2007 S. Karger GmbH, Freiburg \\
Fax +4976145207 14 & Accessible online at: \\
$\begin{array}{l}\text { E-mail Information@Karger.de } \\
\text { www.karger.com }\end{array}$ & www.karger.com/tmh
\end{tabular}




\section{Diagnosis Criteria / Definition for Protein Losing Enteropathy}

Protein losing enteropathy (PLE), a massive enteric loss of serum protein, is usually characterized by a combination of different symptoms which do not have to be present at the same time. PLE appears in several diseases, e.g. in autoimmune diseases such as systemic lupus erythematosus (SLE) or celiac disease, and is often associated with intestinal mucous membrane damages with or without infection.

The medical history, physical examination and some laboratory parameters (table 1 ) are also specific for diseases associated with Fontan surgery (total cavopulmonary connection, TCPC). PLE is rare complication in patients who underwent Fontan surgery which is used to palliate complex congenital heart defects with an univentricular physiology [1]. Depending on the study, 9 [2] to $15 \%$ [3] of the survivors exhibit a substantial enteric protein loss. Time span between operation and the occurrence of PLE varies significantly from months to years after surgery. The mortality of patients with a manifest PLE is $46-59 \%$ after 5 years and $>80 \%$ after 10 years $[3,4]$. Up to now, the etiology of PLE is unknown.

\section{Etiology / Risk Factors}

The mechanism of action of PLE is poorly understood. The current theory of post-Fontan PLE is that chronic venous congestion causes the lymphatics to decompress into low-pressure cavities such as the pleural cavity or abdomen. Loss of proteins and lymphocytes, and an inflammatory response leads to chronic malnutrition resulting in a global immune dysfunction [5].

Systematic investigations correlating the risk factors for PLE with clinical parameters suggest elevated systemic venous pressure as a major contributory factor, which is the inherent hemodynamic component of the Fontan circulation [3]. However, there is no strict hemodynamic difference between those patients who develop PLE and those who do not [3]. Several studies suggest at least a participation of the immune system in the pathogenesis of PLE [6-8].

Recent observations indicate that onset of PLE is the result of multiple insults. It has been suggested that viral or bacterial infection, mostly of the gastric tract, can serve as trigger of PLE onset [7-10]. Jejunal biopsies, taken during episodes with PLE, revealed an increased IFN- $\gamma$ concentration [11], most likely as a response to the viral infection and elevated levels of the pro-inflammatory cytokine TNF- $\alpha$ [12]. Both cytokines are known to impair the integrity of the intestinal epithelial barrier [13]. Similar to other primary diseases associated with PLE (e.g. SLE or celiac disease), episodes of post-Fontan PLE are characterized by a loss of heparan sulfate proteoglycan (HSPG), particularly from the basolateral surface of intestinal epithelial cells. However, neither HSPG expression in the lamina propria nor expression of other matrix components is
Table 1. Required laboratory parameters for diagnosis of PLE

- Elevated fecal $\alpha 1$-antitrypsin secretion (normal range $<100 \mu \mathrm{g} / \mathrm{g}$ ), increased $\alpha 1$-antitrypsin serum level (normal range $0.88-1.74 \mathrm{~g} / \mathrm{l}$ )

- Decreased total serum protein level (normal range 66-87 g/l)

- Decreased serum albumin level (normal range 34-48 g/l)

- Decreased serum g-globulin and increased a1-, $\alpha 2$ - and b-globulin level (normal ranges: $\gamma$-globulin 4.5-12.1 g/l, $\alpha 1$-globulin 0.9-2.9g/1, $\alpha 2$-globulin 5.4-9.3 g/l, $\beta$-globulin 3.5-7.6 g/l)

- No trypsinogen or enterokinase deficiency

- Lymphopenia < 1,500 cells/ $\mu$ (normal range 1,500-3,000 cells/ $\mu \mathrm{l}$ )

- Possible acute inflammation (mostly at the onset of PLE increased IL-6, IL-8, TNF- $\alpha$ serum levels, neutrophilia)

- T cell loss, T helper (T4) cell count massively reduced (down to $<100$ cells $/ \mu \mathrm{l}$ ) (normal range $800-1,500 \mathrm{cells} / \mu \mathrm{l}$ )

- Protein level in urine is normal $(<0.15 \mathrm{~g} / 24 \mathrm{~h})$

influenced. In addition, the intestinal architecture remains intact. The reasons why HSPG is lost during episodes of PLE are still unknown [14].

Genetic factors could play a role in susceptibility to PLE development. Patients with univentricular heart differ from a healthy cohort with respect to the blood coagulation system [15] or the immune system [8] already prior to Fontan palliation. This finding may indicate genetic abnormalities. Reduced heparan sulfate accumulation in enterocytes contributes to PLE in a congenital disorder of glycosylation [16]. Also mesenteric hypoperfusion due to the increased mesenteric vascular resistance could serve as a possible trigger for the PLE development [17]. The results of Chaloupecky et al. [18] support the hypothesis that the abnormalities in the balance of coagulation factors observed in patients after Fontan operation are related to the coagulation factor production in the liver. The passive lymph loss caused by high central venous pressure does not explain the selective loss of CD4+ lymphocytes. Thus, it was suggested that the disturbance of the immune system could affect the structural integrity and patency of the intestinal wall, thereby triggering PLE [19]. The most likely explanation is that genetic factors and Fontan-induced venous hypertension predispose for PLE which appears upon a series of sequential or simultaneous environmental insults.

\section{Clinical Description}

Clinical signs for PLE are edemas, ascites, pleural effusion, diarrhea, malnutrition, fatigue, and weight loss as well as reduced physical development in children. The laboratory parameters required for the differential diagnosis of PLE are summarized in table 1 [data from 7, 8, 12, 19, 20]. Based on these very heterogeneous laboratory findings, PLE after Fontan procedure must be differentiated from

- other diseases with hypoproteinemia,

- other primary intestinal mucous membrane damages or primary lymphangiectasia, 
- congenital enzyme defects (e.g. trypsinogen or enterokinase deficiency), malabsorption, nutrition sensitivity or allergic reactions (gluten, milk components),

- nephrotic syndrome (low serum concentrations of $\gamma$-globulin coinciding with elevated $\alpha 1$-, $\alpha 2$ - and $\beta$-globulin levels are present in both PLE and nephrotic syndrome, but in contrast to nephrotic syndrome patients PLE patients generally do not exhibit proteinuremia),

- acquired (e.g. AIDS) or congenital immunodeficiency because of decreased $\mathrm{T}$ helper (T4) cell counts (up to $<100 / \mu \mathrm{l})$ and $\gamma$-globulin levels,

The diagnosis of PLE is unspecific, even if there is always an elevated fecal concentration of $\alpha 1$-antitrypsin indicating a highly elevated $\alpha 1$-antitrypsin clearance. Nervertheless, since $\alpha 1$-antitrypsin is an acute-phase protein, its increased occurrence in the stool did not allow for an unequivocal doubtless diagnosis of PLE, as this symptom is also associated with other conditions such as enteritis of different origin. In conclusion, it must be emphasized that PLE occurs rarely and in combination with other nonspecific symptoms.

The clinical signs become significant most often after the patient underwent Fontan palliation. PLE with other etiologies such as SLE, pericarditis or after superior vena cava-right pulmonary artery shunt (Glenn) is extremely rare. Many patients suffer from infections from various harmless origins while developing PLE [7]. For this reason patients are rarely examined by a cardiologist at the very beginning of PLE occurrence. Often patients already had edemas caused by hypoproteinemia before they are admitted to a cardiac center.

PLE is often associated with intestinal lymphangiectasia $[3,4$, 21]. Although not yet routinely used for diagnosis, the composition of the peripheral blood of patients with PLE shows a pathognomonic change, i.e. highly selective lymphocyte loss (T4 (CD4+) cell count $<100$ cells/ $\mu \mathrm{l})[7,19,20]$. This selective cell loss which is not yet completely understood leads to a dramatic decrease of the T4/T8 cell ratio similar to that observed in patients with HIV [22, 23]. But in contrast to HIV patients opportunistic infections are rare in PLE patients [20]. The lymphocyte loss leads to the prevalence of unique T lymphocyte subtypes (CD4- CD8-) in the blood circulation [6, 24]. This phenotype of T lymphocytes is known from the autoimmune lymphoproliferative syndrome (ALPS) [25]. It is noteworthy, that already children with Fontan circulation, but without PLE, have an altered immune phenotype [24] compared to age-matched healthy children [26]. However, also the immune phenotype of children with other congenital heart diseases may differ from that of healthy age-related subjects [27].

Therefore a key tool is immunodiagnostics using either flow cytometry [28] or microscopic (or slide-based) cytometry [29]. Both technologies [30] yield quantitative data on the phenotypes and functions of leukocytes and lymphocytes [23, 31, 32] and are increasingly important tools in hemotherapy and transfusion medicine [33, 34]. Furthermore, cytometry can be used to determine the concentration of multiple soluble blood compounds by multiplexed bead arrays using very small sample volumes [35-37].

\section{Management including Treatment}

The prognosis of patients suffering from PLE is poor. Since the pathogenesis is not yet fully understood, there is a broad range of treatments suggested, mostly in single case reports. Therapy considerations should have the aim to decrease central venous pressure to improve hemodynamics. Relief of potential obstructions in the Fontan pathway, conversion of a classical atriopulmonary anastomosis with loss of kinetic blood energy due to severe atrial dilatation to a total cavopulmonary connection or creation of a fenestration between the systemic venous and pulmonary venous atrium are possible surgical options.

The current medication consists of the substitution of albumin and/or $\gamma$-globulin [38] in combination with diuretics but has often only a temporary effect. In few patients PLE resolves without any obvious correlation to therapy. Case reports indicate that treatment with steroids, heparin, somatostatin analogues or high-dose spironolactone can lead to an improvement $[11,12,21,39]$. Thus, anti-inflammatory therapy can at least temporarily reduce TNF- $\alpha$ levels, and substitution of heparin can diminish the protein loss by stabilizing the cell membrane of the intestinal mucosa [39, 40]. Cure of PLE in sarcoidosis by calcium substitution or anti-TNF agents indicating allergic or other immunological etiologies have been demonstrated. Furthermore, special diets (high protein, low fat with mediumchain triglycerides and essential fatty acids) are suggested.

None of these treatments seem to be successful for all patients, reflecting the multifactorial origin of PLE. Correspondingly, a detailed European study showed that, in spite of surgical intervention or medication, still $>60 \%$ of the patients remain symptomatic [3] and that the 10-year survival rate of patients suffering from PLE is only $10-20 \%$. For some, but not all, patients with PLE the ultimate option is a heart transplantation [41].

\section{Prospects}

Intensive studies about the reasons of PLE are needed to develop therapies in the future. In our opinion, the monitoring of the changes of the immune phenotype could be used to predict the PLE risk [8]. The difficulties of analyzing the changes in the immune phenotype could be overcome by using cytometric blood analysis [33]. The use of multiple analytes for a rapid analysis of a multitude of cells and for the recognition of specific cell types $[29,42]$ in combination with mathematical analysis $[9,28,43]$ could help to assess the risk of patients and to individualize the therapy $[44,45]$. 


\section{References}

1 Fontan F: Atrio-pulmonary conduit operations for tricuspid atresia and single ventricle. Nippon Kyobu Geka Gakkai Zasshi 1978;26:276-284.

2 Earing MG, Cetta F, Driscoll DJ, Mair DD, Hodge DO, Dearani JA, Puga FJ, Danielson GK, O'Leary PW: Long-term results of the Fontan operation for double-inlet left ventricle. Am J Cardiol 2005;96 (2):291-298.

>3 Mertens L, Hagler DJ, Sauer U, Somerville J, Gewillig M: Protein-losing enteropathy after the Fontan operation: an international multicenter study. J Thorac Cardiovasc Surg 1998;115 1063-1073.

4 Thorne SA, Hooper J, Kemp M, Somerville J: Gastro-intestinal protein loss in late survivors of Fontan surgery and other congenital heart disease. Eur Heart J 1998;19:514-520.

$\checkmark 5$ Setty SP, Herrington CS: Fontan procedure: old lessons and new frontiers. Expert Rev Cardiovasc Ther 2006;4(4):515-521.

6 Lenz D, Bocsi J, Hambsch J, Daehnert I, Schneider P, Tárnok A: Chronic inflammation with or without Fontan palliation in univentricular heart patients. Cytometry A 2006;69A(1):57-58.

7 Lenz D, Hambsch J, Schneider P, Hausler HJ, Sauer U, Hess J, Tárnok A: Protein-losing enteropathy in patients with Fontan circulation: is it triggered by infection? Crit Care 2003;7(2):185-190.

8 Lenz D, Hambsch J, Schneider P, Tárnok A. Protein-losing enteropathy after Fontan surgery: is assessment of risk patients with immunological data possible? Cytometry B Clin Cytom 2003;53B(1): 34-39.

9 Tárnok A, Valet GK, Emmrich F: Systems biology and clinical cytomics: The 10th Leipziger Workshop and the 3rd International Workshop on SlideBased Cytometry, Leipzig, Germany, April 2005. Cytometry A 2006;69A(1):36-40.

10 Bode L, Freeze HH: Applied glycoproteomics - approaches to study genetic-environmental collisions causing protein-losing enteropathy. Biochim Biophys Acta 2006;1760(4):547-59.

-11 Shimizu T, Nagata S, Fuji T, Takahashi K, Kishiro M, Okhubo M, Akimoto K, Yamashiro Y: Enhanced production of interferon-gamma as a possible cause of protein-losing enteropathy after modified Fontan operation. J Pediatr Gastroenterol Nutr 2003;37:504-507

12 Ostrow AM, Freeze H, Rychik J: Protein-losing enteropathy after Fontan operation: investigations into possible pathophysiologic mechanisms. Ann Thorac Surg 2006;82(2):695-700.

13 Bruewer M, Luegering A, Kucharzik T, Parkos CA, Madara JL, Hopkins AM, Nusrat A: Proinflammatory cytokines disrupt epithelial barrier function by apoptosis-independent mechanisms. J Immunol 2003;171(11):6164-6172.

14 Bode L, Murch S, Freeze HH: Heparan sulfate plays a central role in a dynamic in vitro model of protein-losing enteropathy. J Biol Chem 2006;281 (12):7809-7815.

15 Odegard KC, McGowan FX, Zurakowski D, DiNardo JA, Castro RA, del Nido PJ, Laussen PC: Coagulation factor abnormalities in patients with single-ventricle physiology immediately prior to the Fontan procedure. Ann Thorac Surg 2002;73(6): 1770-1777.
16 Westphal V, Murch S, Kim S, Srikrishna G, Winchester B, Day R, Freeze HH: Reduced heparan sulfate accumulation in enterocytes contributes to protein-losing enteropathy in a congenital disorder of glycosylation. Am J Pathol 2000;157(6): 1917-1925.

17 Rychik J, Gui-Yang S: Relation of mesenteric vascular resistance after Fontan operation and proteinlosing enteropathy. Am J Cardiol 2002;90(6): 672-674.

18 Chaloupecky V, Svobodova I, Hadacova I, Tomek $\mathrm{V}$, Hucin B, Tlaskal T, Janousek J, Reich O, Skovranek J: Coagulation profile and liver function in 102 patients after total cavopulmonary connection at mid term follow up. Heart 2005;91(1):73-79.

19 Koch A, Hofbeck M, Feistel H, Buheitel G, Singer $\mathrm{H}$ : Circumscribed intestinal protein loss with deficiency in CD4+ lymphocytes after Fontan procedure. Eur J Pediatr 1999;158:847-850.

20 Cheung YF, Tsang HYF, Kwok JSY: Immunologic profile of patients with protein losing enteropathy complicating congenital heart disease. Pediatr Cardiol 2002;23:587-593.

21 Donnelly JP, Rosenthal A, Castle VP, Holmes RD: Reversal of protein-losing enteropathy with heparin therapy in three patients with univentricular hearts and Fontan palliation. J Pediatr 1997;130: 474-478.

22 Zaccarelli-Filho CA, Ono E, Machado DM, Brunialti M, Succi RC, Salomao R, Kallas EG, de Moraes-Pinto MI: HIV-1-infected children on HAART: immunologic features of three different levels of viral suppression. Cytometry B Clin Cytom 2007;72B(1):14-21.

23 Pattanapanyasat K, Shain H, Noulsri E, Lerdwana S, Thepthai C, Prasertsilpa V, Likanonsakul S, Yothipitak P, Nookhai S, Eksaengsri A. A multicenter evaluation of the PanLeucogating method and the use of generic monoclonal antibody reagents for CD4 enumeration in HIV-infected patients in Thailand. Cytometry B Clin Cytom 2005; 65B(1):29-36.

24 Bocsi J, Lenz D, Sauer U, Wild L, Hess J, Schneider P, Hambsch J, Schranz D, Tárnok A: Inflammation and immune suppression following protein losing enteropathy after Fontan surgery detected by cytomics. Transfus Med Hemother 2007;34(3): 168-175.

25 Brawura-Biskupski-Samaha R, Grzela T: Autoimmune lymphoproliferative syndrome-impaired regulation of the immune response by impaired induction of apoptosis. Transfus Med Hemother 2006:33 (1):71-79.

26 Sack U, Gerling F, Tárnok A: Age related lymphocyte subset changes in the peripheral blood of healthy children. A meta-study. Transfus Med Hemother 2007;34(3):176-181.

27 Tárnok A, Schneider P: Pediatric cardiac surgery with cardiopulmonary bypass: pathways contributing to transient systemic immune suppression. Shock 2001;16(suppl 1):24-32.

28 Petrausch U, Haley D, Miller W, Floyd K, Urba WJ, Walker E: Polychromatic flow cytometry: a rapid method for the reduction and analysis of complex multiparameter data. Cytometry A 2006;69A(12): 1162-73.
29 Mittag A, Lenz D, Gerstner AO, Tárnok A. Hyperchromatic cytometry principles for cytomics using slide based cytometry. Cytometry A 2006;69A(7): 691-703.

30 Shapiro HM, Perlmutter NG: Personal cytometers: slow flow or no flow? Cytometry A 2006;69A(7): 620-30.

31 Barten MJ, Rahmel A, Bocsi J, Boldt A, Garbade J, Dhein S, Mohr FW, Gummert JF: Cytokine analysis to predict immunosuppression. Cytometry A 2006; 69A(3):155-157.

32 Gille C, Orlikowsky T: Flow cytometric methods in the detection of neonatal infection. Transfus Med Hemother 2007;34(3):157-163.

33 Schlenke P: Leukocyte reduction in blood component supply: the impact of flow cytometry in assessing residual leukocytes. Transfus Med Hemother 2005:32(1):12-19.

34 Stahl D: Current concepts on immune regulation: impact on scientific and clinical aspects of immunohematology Transfus Med Hemother 2005;32(6): 293-295.

35 Sack U, Scheibe R, Wotzel M, Hammerschmidt S, Kuhn H, Emmrich F, Hoheisel G, Wirtz H, Gessner C: Multiplex analysis of cytokines in exhaled breath condensate. Cytometry A 2006;69A(3):169-172.

36 Laffers W, Schlenkhoff C, Kristina Pieper K, Mittag M, Tárnok A, Gerstner AOH. Concepts for absolute immunophenosubtyping by slide-based cytometry. Transfus Med Hemother 2007;34(3): 188-194.

37 Bocsi J, Richter M, Hambsch J, Barten MJ, Dahnert I, Schneider P, Tárnok A. Transient Th1/Th2 disbalance indicates postoperative effusions and edema after cardiopulmonary bypass in children. Cytometry A 2006;69A(3):165-168.

38 Hasskarl H: Zur Zulässigkeit der Umsetzung der EG-Blutrichtlinien 2002/98/EG und 2004/33/EG in nationales Recht durch Richtlinien der Bundesärztekammer nach $\S \S 12$ und 18 Transfusionsgesetz. Transfus Med Hemother 2005;32:34-41.

39 Rychik J, Spray TL: Strategies to treat protein-losing enteropathy. Semin Thorac Cardiovasc Surg Pediatr Card Surg Annu 2002;5:3-11.

40 Pötzsch B, Müller J, Rox JM: Developmental strategies of novel anticoagulants. Transfus Med Hemother 2006;33(2):200-204.

41 Hosseinpour AR, Cullen S, Tsang VT: Transplantation for adults with congenital heart disease. Eur J Cardiothorac Surg 2006;30(3):508-514.

42 Tárnok A, Bocsi J, Brockhoff G: Cytomics - importance of multimodal analysis of cell function and proliferation in oncology. Cell Prolif 2006;39(6): 495-505.

43 Valet G: Human cytome project, cytomics, and systems biology: the incentive for new horizons in cytometry. Cytometry A 2005;64A(1):1-2.

44 Lenz D, Barten MJ, Hiller S, Tárnok A, Sack U: Regenerative and predictive medicine of cardiovascular disease: the 9th Leipziger Workshop and the 2nd International Workshop on slide based cytometry. Cytometry A 2005;64A(2):110-114.

45 Valet G: Diagnostic versus predictive flow cytometry. Lab Hematol 2004;10(3):166-168. 